\title{
B-Cell Lymphoma/Leukemia 11B
}

National Cancer Institute

\section{Source}

National Cancer Institute. B-Cell Lymphoma/Leukemia 11B. NCI Thesaurus. Code C91857.

B-cell lymphoma/leukemia 11B (894 aa, $\sim 96 \mathrm{kDa}$ ) is encoded by the human BCL11B gene. This protein may play a role in the modulation of p53-mediated signaling, tumor suppression and T cell development. 